\title{
VERSENYKÉPESSÉG AZ AUTÓIPARI ELLÁTÁSI LÁNCBAN - ALAPVETŐ KÉPESSÉGEK AZ EGYES BESZÁLLÍTÓ TÍPUSOK ESETÉBEN
}

J`len tanulmány szorosan kapcsolódik Gelei - Nagy (2004) munkájához, amelyben a hazai autóipari ellátási láncok esetén vizsgálják a beszállító-megrendelő kapcsolatokban jelentkező vevői értéket, illetve annak összetevőit. Ebben az írásban a szerző arra vállalkozik, hogy a Gelei - Nagy (2004) által bemutatott elméleti keretet felhasználva, valós vállalati példákon keresztül keresse az összefüggést a vállalatok alapvető képessége és a vevőik számára nyújtott értékek között. Ez a munka nem öncélú, hiszen a vevők számára teremtett érték jelentősen meghatározza a vállalat versenyképességét, azon keresztül pedig müködésének eredményességét.

Jelen tanulmány az autóipari beszállító-vevő kapcsolatokat vizsgálja, azt az összefüggést, ahogyan a beszállító képességei alkalmazásával erőforrásai felhasználása mellett vevői számára értéket teremt, amellyel önmaga versenyképességét növeli. Az 1. ábra bemutatja a modellben felhasznált fogalmak kapcsolatát. A versenyképesség definíció szerint képesség a környezeti és a belső (vállalaton belüli) változások érzékelésére, és az ezekhez való alkalmazkodásra oly módon, hogy a vállalat nyereségfolyama lehetővé tegye a tartós működőképességet (Chikán, 2001). Az alapvetó (vagy lényegi-) képesség alatt a vállalatok számára fenntartható versenyelőnyt biztosító sajátos képességeket (Chikán, 2003) értjük. A kutatási modell harmadik kulcstényezője a vevői érték. Vevői érték akkor képződik, ha a vevő adott tranzakcióból származó haszna meghaladja a kapott termék és a hozzá tartozó szolgáltatáscsomag tulajdonlásának teljes költségét (a termék felkutatása, szerződéskötés, szállítás, karbantartási költségek stb.) (Chikán - Demeter (szerk.), 1999).

Gelei (2004) e három terület összefüggését a következőképpen adta meg: a vállalati versenyképesség nagymértékben függ attól, hogy egy vállalat mennyire képes azonosítani a vevő által értéknek ítélt tényezőket
1. ábra

A versenyképesség két összetevője (Gelei, 2004)

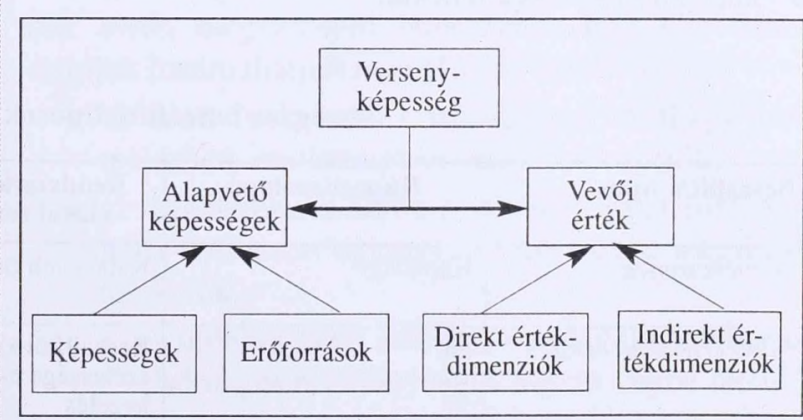

(termék- és szolgáltatásjellemzők, információk stb.), milyen mértékben képes felmérni és saját nyelvére lefordítani a vevők kimondott (vagy ki nem mondott) igényeit, elvárásait. Bárhogyan is sikerül ez a kódolás, a vállalat számára a továbbiakban a cél ezen elvárások minél teljesebb kielégítése lesz (feltételezzük a vállalat racionális viselkedését). A vevő részéről a kapott érték maximalizálásának igénye lesz az a kritérium, amely alapján beszállítóit kiválasztja. A vállalat szempontjából az értékteremtés eszközei egyrészt az erőforrások, másrészt azok az eljárások (rutinok), amelyek által az erőforrások megfelelő kombinálásával és átalakításával a vevő számára fontos érték létrejön. Grant (1991, 
120. o.) szerint a vállalat képessége nem más, mint mindaz, amit erőforrásai csoportjainak együttműködése által megtenni képes.

Gelei - Nagy (2004) munkájukban a hazai autóipari ellátási láncok esetén a beszállító-megrendelő kapcsolatokban jelentkező vevői értéket, illetve annak összetevőit azonosították, tipizálását bemutatták. Jelen írásomban az ő eredményeikre támaszkodva, a versenyképesség másik összetevőjének, az alapvető képességnek felépülését (részképességekből és erőforrásokból) vizsgálom konkrét vállalati példák felhasználásával.

\section{Az elméleti keretek rövid bemutatása}

Gelei - Nagy (2004) szerzőpáros definiálja, illetve a magyar autóipari beszállítók esetében azonosítja is azokat az értékdimenziókat, amelyeket relevánsnak tart magyarországi viszonylatban:

- ár,

- a specifikációnak megfelelő minőség,

- a kiszolgálási szint megbízhatósága - teljesítések pontossága,

- mennyiségi dimenzió - gyártási volumen biztosítása,

- biztonsági dimenzió - hosszú távú működési stabilitás,

- kapcsolódó szolgáltatások,
- rugalmasság - vevői igények rövid távú változásához való alkalmazkodás,

- innovációs dimenzió - inkrementális- és stratégiai fejlesztések,

- felderítő dimenzió - új információkhoz való hozzáférés,

- hozzáférési dimenzió - új szereplőkhöz való hozzáférés.

Az autóipari ellátási beszállítókat az alábbi kategóriákba csoportosította alapvető képességeik alapján:

- kapacitásalapú kompetencia - termelőkapacitását ajánlja fel,

- rendszerkompetencia - a vevő további beszállítóit is koordinálja,

- adaptációs kompetencia - a termék gyártásán túl kis lépésekben való fejlesztésre is képes,

- innovációs kompetencia - jelentős mértékű fejlesztések felkínálása.

A szerzópáros négy táblázatban bemutatja az alapvetô képességek és a vevőik számára teremtett értékek kapcsolatát is.

Az ismeretek további összegzését adja Gelei (2004) azáltal, hogy a négy alapvető képességgel bíró csoport fő jellemzőit egy táblázatban foglalja össze. (1. táblázat).

1. táblázat

Az egyes beszállító típusok és jellemzőik (Gelei 2004)

\begin{tabular}{|c|c|c|c|c|}
\hline Beszállítói típus & Kapacitásalapú & $\begin{array}{l}\text { Rendszerkompeten- } \\
\text { ciával rendelkezố }\end{array}$ & Adaptációalapú & Innovatívalapú \\
\hline Termékcsomag & Kapacitás & Kapcsolati háló & $\begin{array}{l}\text { Termékismeret és } \\
\text { technológia }\end{array}$ & $\begin{array}{l}\text { Magas innovációs képes- } \\
\text { ség }\end{array}$ \\
\hline Föbb értékdimenziók & Ár & $\begin{array}{l}\text { Beszállítói kapcsolatok } \\
\text { szélessége és kapcsolat- } \\
\text { kezelés }\end{array}$ & Rugalmasság & Innováció \\
\hline Alapvető képesség & $\begin{array}{l}\text { Gazdaságos termelési } \\
\text { képesség }\end{array}$ & Hálózati képesség & $\begin{array}{l}\text { Inkrementális innovációs } \\
\text { képesség }\end{array}$ & $\begin{array}{l}\text { Stratégiai innovációs } \\
\text { képesség }\end{array}$ \\
\hline $\begin{array}{l}\text { Legfontosabb erőforrá- } \\
\text { sok }\end{array}$ & $\begin{array}{l}\text { Olcsó munkaerő, alkal- } \\
\text { mazott technológia }\end{array}$ & $\begin{array}{l}\text { Integrált, a partnerekkel } \\
\text { összeköttetésben lévổ } \\
\text { információs rendszer }\end{array}$ & $\begin{array}{l}\text { Képzett, tapasztalt mun- } \\
\text { kaerô }\end{array}$ & $\begin{array}{l}\text { Magasan képzett } \mathrm{K}+\mathrm{F} \\
\text { alkalmazottak } \\
\text { Legfejlettebb kutatási } \\
\text { technológia beszerzése }\end{array}$ \\
\hline $\begin{array}{l}\text { Legfontosabb részképes- } \\
\text { ségek }\end{array}$ & $\begin{array}{l}\text { Gyártási folyamat szer- } \\
\text { vezettsége }\end{array}$ & $\begin{array}{l}\text { Hatékony beszállító-érté- } \\
\text { kelés és kiválasztás. } \\
\text { Jó koordinációs, és prob- } \\
\text { lémamegoldó képesség }\end{array}$ & $\begin{array}{l}\text { A vevő igényeinek meg- } \\
\text { értési képessége } \\
\text { Hatékony termelési ké- } \\
\text { pesség }\end{array}$ & $\begin{array}{l}\text { Technológiai és piaci } \\
\text { trendek jó felismerési } \\
\text { képessége } \\
\text { Stratégiai partnerkapcso- } \\
\text { latok kialakításának és } \\
\text { hatékonymenedzsmentjé } \\
\text { nek képessége }\end{array}$ \\
\hline Kapcsolattípus & $\begin{array}{l}\text { Rövid távú - piaci } \\
\text { cserekapcsolat }\end{array}$ & Középtávú - kooperáció & Középtávú - kooperáció & $\begin{array}{l}\text { Hosszú távú - stratégiai } \\
\text { partnerkapcsolatok }\end{array}$ \\
\hline Alkuerö & \multicolumn{4}{|c|}{ Növekvő } \\
\hline
\end{tabular}


$\mathrm{Az}$ 1. táblázat tartalmazza nemcsak az alapvető kompetenciák alapján kialakított beszállítói tịpusokhoz hozzárendelhető főbb értékdimenziókat, de tartalmazza a legjellemzőbb erőforrásokat és részképességeket is. A táblázatból kiderül, hogy az egyes beszállító típusok kapcsolataikban különböző alkuerővel bírnak. Gelei szerint az a beszállító rendelkezik a legcsekélyebb alkuerővel, aki csupán rendelkezésre álló kapacitásait ajánlja fel vevőinek, míg az a vállalat, amely képes jelentős mértékű fejlesztéseket megvalósítani erősebb pozíciót foglalhat el a tárgyalások során.

A továbbiakban célunk ezen elméleti modellekre támaszkodva megvizsgálni a magyar autóiparban müködő néhány beszállító esetén keresztül a képességek, az erőforrások és a vevői értékek kapcsolatát. A képességek és az erőforrások vizsgálatához azonban még hiányzik e fogalmak tisztázása.

\section{Alapvető képesség, képességek, erőforrások}

Egy vállalat alapvetô képességeinek feltárásakor logikus először a vállalat rendelkezésre álló erőforrásait számba venni. Ezt sugallja a vállalatok értékelésének klasszikus módja, a könyv szerinti érték meghatározása is. Ekkor számba vesszük mindazokat a javakat és eszközöket, amelyek a számviteli szabályoknak megfelelően megjelennek a kimutatásokban. Ezek lehetnek gépek, berendezések, pénzeszközök (tárgyiasult eszközök) vagy pl. szabadalmi jogok (immateriális javak). A nem tárgyiasult erőforrások között viszont léteznek olyanok is, amelyeket a számviteli kimutatások nem (vagy csak részben) vesznek számításba. Ilyen lehet pl. , a márkanév, a hírnév és nem utolsó sorban a dolgozók szaktudása, nyelvismerete, sőt motivációi is, azaz a rendelkezésre álló humán erőforrások. (Az erőforrások csoportosítását á 2. táblázat mutatja.)

2. táblázat

Az erőforrások csoportosítása (Grant, 1991)

\begin{tabular}{|l|l|l|}
\hline \multicolumn{2}{|l|}{ Erőforrások } & Példák \\
\hline \multirow{2}{*}{$\begin{array}{l}\text { Tárgyiasult } \\
\text { erőforrások }\end{array}$} & Pénzügyi & Fizikai \\
\cline { 2 - 3 } $\begin{array}{l}\text { Nem } \\
\text { tárgyiasult } \\
\text { erôforrások }\end{array}$ & Technológiai & Gépek, készletek \\
\cline { 2 - 3 } & Hírnév & Licencek \\
\cline { 2 - 3 } & Kultúra & $\begin{array}{l}\text { Visszatérō vásárlók } \\
\text { aránya }\end{array}$ \\
\hline \multirow{2}{*}{$\begin{array}{l}\text { Emberi } \\
\text { erôforrások }\end{array}$} & Szaktudás & $\begin{array}{l}\text { Elfogadott értékek, } \\
\text { tradíciók }\end{array}$ \\
\cline { 2 - 3 } & Kommunikációs készség & $\begin{array}{l}\text { Mérnöki ismeretek, } \\
\text { hegesztő }\end{array}$ \\
\cline { 2 - 3 } & Motiváció & Tudásvágy \\
\hline
\end{tabular}

Ha azonban azt vizsgáljuk, hogy az erőforrások tömegéből hogyan keletkezik az a képesség, amely valamilyen szempontból a versenytársak fölé emeli a vállalatot (azaz az alapvető képesség), akkor nyilvánvaló, hogy az erőforrásokon túl van még valami, ami az erőforrások másokétól eltérô módon való hasznosítását lehetővé teszi. Ezeket nevezzük képességeknek.

Hogy mi önmagában a képesség? Koordinációs minták vagy rutinok (Nelson - Winter, 1982), amelyek segítenek az erőforrások hatékony felhasználásában. Olyan ismeret, tudás, amely kijelöli az erőforrások egyes csoportjai közötti interakciókat, azok koordinációját, együttműködését. Az erőforrások megléte önmagában nem záloga a sikernek, szükségesek hozzá a hatékony felhasználás folyamatát ismerő rutinok is.

A képességek jelentik tehát az erőforrások felhasználásának mikéntjét, illetve az azok közötti valamiféle kölcsönhatást. Ennek megfelelően ez a kölcsönhatás több szinten mehet végbe. Így más jellegű képességekre lesz szükség a termelésben egy műhely szintú együttműködés során (ahol a dolgozók azonos szaknyelvet használnak, hasonló motivációval rendelkeznek stb.) és egészen más egy új termék fejlesztésénél, ahol a vevői igények felmérésétôl a technológiai jellemzők figyelembevételéig sok szempontú koordináció szükséges.

Ennek megfelelően a szervezet működésének, s ennek során megvalósuló interakcióinak a következó szintjeit határozhatjuk meg (Gelei, 2004):

- az adott funkcionális szervezeten belül (pl. termelésben, marketingben) zajló interakciók,

- az értékteremtés során a vállalat egyes funkcionális szervezeti egységei között végbe menő interakciók,

- ez utóbbin belül érdemes megkülönböztetni az elsődleges tevékenységek között végbe menő,

- valamint az ennél tágabb, a támogató funkciókat is magában foglaló szervezeti egységek közötti interakciókat (Porter, 1985),

- végül a szereplők közötti interakció végbe mehet a szervezet határain túl is az együttmúködô vállalatok között.

Példaként említhetjük a YKK ${ }^{2}$ esetét, ahol a termelési funkció hatékony megvalósítása az alapvető képesség, vagy az Amazon.com, amely a disztribúció és az ahhoz kapcsolódó szolgáltatások megvalósításában szerzett jelentős előnyt. További példa lehet még a General Electric a szerteágazó üzleti területek sikeres menedzsmentjében vagy a Nokia a formatervezésben. 
A képességek a funkcionális területektől kiindulva az összvállalati (esetleg vállalatok közötti) együttműködés felé haladva egyre összetettebbé válnak, egyre inkább szociális jelleget öltenek, egyre inkább megfoghatatlanok. A képességek egymásra épülnek, a kevésbé összetett részképességek hozzák létre azt az alapvető képességet, amely a vállalatot képes megkülönböztetni versenytársaitól, és amely a vállalat versenyképességéhez is vezet (2. ábra).

2. ábra

A képességek egymásra épülése (Gelei, 2004)

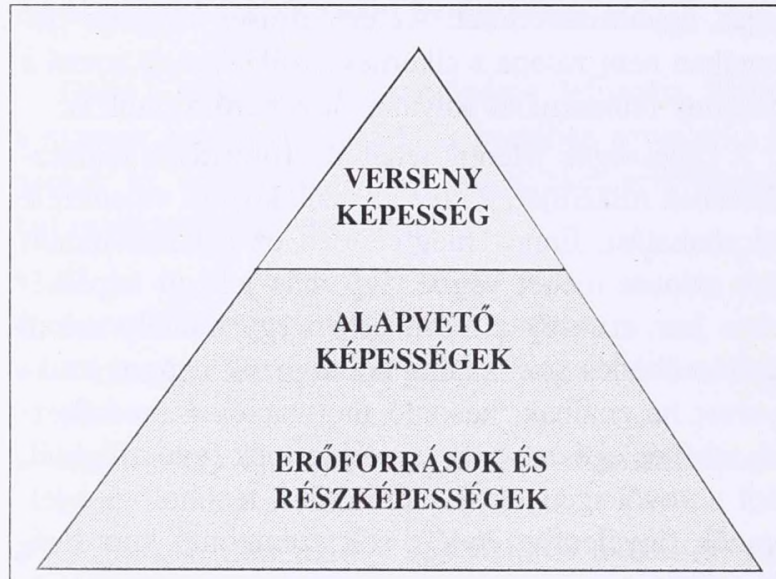

Az elméleti irodalom és a korábbi kutatások tapasztalatainak összevetése

A korábban már említett „A vállalati stratégia hatása az ellátási lánc menedzsmenteszközeire" címú kutatás lehetőséget teremtett különbözó autóipari beszállító vállalatok megismerésére. Az ő példájuk lehet az alapja egy elemzésnek, amely alkalmas hipotézisek előállítására, illetve azok első tesztelésére.

\section{A kutatásban ${ }^{3}$ részt vevő beszállitó vállalatok alapvetö képességei}

A kutatás során interjúkat készítettünk különböző vállalatok vezetőivel, akik jellemzően felső vezetői, beszerzési vagy értékesítési vezetői az adott vállalatnak. Az interjúk után összegyűjtöttük azokat a vállalati jellemzőket, amelyek (a kutatók véleménye szerint) a vállalat számára versenyelőny-forrást jelentettek, azaz hozzájárultak a vállalat hosszú távon is eredményes múködéséhez. A 3. táblázat tartalmazza (a Bosch kivételével) a kutatásban szereplő beszállító vállalatok kompetenciáit (Lásd a 25. oldalt).
A táblázatban csak a vizsgált beszállítói kapcsolataikra jellemző kompetenciákat emeltük ki (azaz vagy a Suzuki vagy az Audi ellátási láncához kapcsolódó tevékenységüket), ami természetesen nem jelenti azt, hogy a vállalat más ellátási láncokhoz kapcsolódva ne viselkednék (legalábbis némileg) más módon. MüllerStewens és Gocke szerint vannak vállalatok, amelyek kizárólag gyártási kompetenciájukat ajánlják fel vevőiknek.

Esetünkben a Beszállító B nagyjából ezt teszi, habár rendelkezésére áll olyan tervezőkapacitás, amelyet az adott termék fejlesztéséhez fel tudna használni, tapasztalataink szerint azonban nem teszi meg, így a mostani vizsgálatunk szempontjából ez a tény elhanyagolható.

A következő vizsgált csoport a Rendszerkompetenciával rendelkező vállalatok köre. Ilyennek tekinthető Beszállító C, amely fejlesztő tevékenységet nem végez, azonban mégis több valamivel a kapacitást felkínáló társánál, hiszen vevője számára külön szolgáltatásként annak másfél tucat beszállítóját koordinálja. A Beszállító C köt szerződést a beszállítókkal, azoktól a vevő felé átvállalja a minőségért való felelősséget is, még abban az esetben is, amikor ő maga az adott terméken semmiféle beavatkozást/módosítást nem végez.

A hármas csoportosítás alapján az összes többi vállalatnak az innovációs kompetenciájú vállalatok közé kellene tartoznia. Nézzük meg hát, hogy ez valóban helytálló-e?

Beszállító D kizárólagos birtokosa annak a licencnek, amely alapján termékét gyártja. Ennek ellenére a terméket magát nem ô fejlesztette ki. Végez azonban fejlesztéseket a terméken, módosítva így az eredeti konstrukciót, fejlesztésével értéket teremtve vevője számára.

A Beszállító $\mathbf{E}$ esetében szintén egy licenc megvásárlásával kezdődött a jelenlegi termék gyártása, amelyet idóközben továbbfejlesztettek. A Beszállító E terméke (amelyet a Suzukinak szállít) egy viszonylag komplex termék, amelynek előállításakor felhasználnak saját beszállítóik által gyártott alkatrészeket.

Hasonló mondható el a Beszállító $\mathbf{H}$ és a Beszállító I esetében is, azzal a különbséggel, hogy ők saját fejlesztésű, komplett terméket kínálnak vevőiknek. Ez azt jelenti, hogy maguk hordozzák a termékfejlesztéshez szükséges kompetenciát, menedzselik a beszállítóik körét. Ami mégis megkülönbözteti őket a klaszszikus autóipari első vonalas rendszerintegrátoroktól, hogy az ő termékeik még mindig nem közvetlenül jutnak el a végtermék gyártójához, csupán beszállítói a 
A vizsgált vállalatok alapvető kompetenciái

\begin{tabular}{|c|c|c|c|}
\hline Vállalatok & $\begin{array}{c}\text { Alapvető } \\
\text { képességek }\end{array}$ & Erôforrások & Képességek \\
\hline Beszállító A & $\begin{array}{l}\text { Jelentős kapacitások, ma- } \\
\text { gas technikai színvonal }\end{array}$ & $\begin{array}{l}\text { Magas színvonalú, rugalmas gyártóberendezé- } \\
\text { sek, jól képzett gépkezelôk, olcsó munkaerố }\end{array}$ & $\begin{array}{l}\text { Partner a fejlesztésben, minőségbiztosítási } \\
\text { rendszer }\end{array}$ \\
\hline Beszállító B & $\begin{array}{l}\text { Elégséges kapacitás, meg- } \\
\text { felelô minôség és ár }\end{array}$ & Elegendỏ kapacitás, képzett munkaerő & $\begin{array}{l}\text { Line Sequence beszállítás, minôségbiztosí- } \\
\text { tási rendszer, késztermék șzállító }\end{array}$ \\
\hline Beszállító C & Megfelelő kapacitás & $\begin{array}{l}\text { Jelentôs kapacitás, nagy volumen, tôkeerôs } \\
\text { anyavállalat, sok vevő }\end{array}$ & $\begin{array}{l}\text { Alacsony egységköltség, vevôorientáció, } \\
\text { minőségbiztosítási rendszer }\end{array}$ \\
\hline Beszállító D & Adaptált termék szállítója & $\begin{array}{l}\text { Kizárólagos licencbirtokos, speciális technoló- } \\
\text { gia, jól képzett-, nagy tapasztalattal rendelke- } \\
\text { zó múszaki vezető-tulajdonos }\end{array}$ & $\begin{array}{l}\text { Rugalmas alkalmazkodás a vevői igények- } \\
\text { hez, termék- és technológiafejlesztés, mi- } \\
\text { nóségbiztosítási rendszer, JIT szállítás }\end{array}$ \\
\hline Beszállító $\mathbf{E}$ & Adaptált termék szállítója & $\begin{array}{l}\text { Szerszámtervezés- és gyártási kapacitás, fej- } \\
\text { lesztő kapacitás }\end{array}$ & $\begin{array}{l}\text { JIT szállítás, minőségbiztosítási rendszer, } \\
\text { diverzifikált termékszerkezet, késztermék } \\
\text { szállítása }\end{array}$ \\
\hline Beszállító F & Adaptált termék szállítója & $\begin{array}{l}\text { Gyártástechnológia- és termékfejlesztési kapa- } \\
\text { citás }\end{array}$ & $\begin{array}{l}\text { JIT beszállítás, minőségbiztosítási rendszer, } \\
\text { diverzifikált termékszerkezet }\end{array}$ \\
\hline Beszállító G & Adaptált termék szállítója & $\begin{array}{l}\text { Tulajdonosi kapcsolatok, tulajdonos-me- } \\
\text { nedzser, olcsó munkaerô, korszerű eszközök }\end{array}$ & $\begin{array}{l}\text { Szerszámtervezés és gyártási kép., minőség- } \\
\text { biztosítási rendszer, jó kapcsolat a vevôvel }\end{array}$ \\
\hline Beszállító $\mathbf{H}$ & $\begin{array}{l}\text { Saját fejlesztésủ termék } \\
\text { beszállító }\end{array}$ & $\begin{array}{l}\text { Felkészült fejlesztőgárda, jól képzett dolgozók } \\
\text { a termelésben, dinamikus vezetők }\end{array}$ & $\begin{array}{l}\text { Folyamatos termékfejlesztés, komplett } \\
\text { megoldások szállítása, Jó kommunikáció a } \\
\text { vevővel, diverzifikált termékszerkezet }\end{array}$ \\
\hline Beszállító I & $\begin{array}{l}\text { Saját fejlesztésű termék } \\
\text { beszállító }\end{array}$ & $\begin{array}{l}\text { Szerszámtervezés- és gyártási kapacitás, fej- } \\
\text { lesztő kapacitás, felkészült vezető, jól képzett } \\
\text { dolgozók, bővülő kapacitás }\end{array}$ & $\begin{array}{l}\text { Gyors átállások, minőségbiztosítási rend- } \\
\text { szer, késztermékek szállítása, diverzifikált } \\
\text { termékszerkezet }\end{array}$ \\
\hline
\end{tabular}

még komplexebb modulokat ${ }^{4}$ létrehozó első körös beszállító gyártójának (pl. a Beszállító I esetében, aki a Bosch-on kersztül szállít az autógyártóknak).

Jó példa az autóipari ellátási lánc változására a Beszállító H esete, aki szórófej-rendszereket állít elő és szállít (jelenleg még közvetlenül) az autógyártónak (Opel, Suzuki). Azonban az autógyártóknak az a törekvése, hogy a közvetlen beszállítók számát csökkentsék, ahhoz vezet, hogy a jövőben a Beszállító $\mathrm{H}$ nem szállíthat csak szórófejeket. Az autógyártó elvárja, hogy egyetlen beszállító legyen képes a teljes mosórendszert szolgáltatni (tartály, szivattyú, csövek, szórófejek, kapcsolók, érzékelők stb.). Ennek megfelelően a Beszállító $\mathrm{H}$ két lehetőség közül választhat. 1) Megelégszik a másodkörös beszállítói ranggal, és beszállítója lesz a magasabb értékű szivattyú beszállítójának (aki ezáltal képes lesz komplett terméket szállítani), vagy 2) önmaga is versenybe száll egy rendszer-integrátori szerep elnyeréséért, és képessé teszi magát a rendszer többi elemének beszerzésére, a termék összeszerelésére. Ez jelentené a szállított termék értékének többszöröződését, valamint a saját beszállítói számának jelentős növekedését (az ehhez kapcsolódó logisztikai problémákkal együtt). Ebből a példából jól látszik a rendszerintegrátori szerep több szintje. (Komplett szórófej vagy komplett mosórendszer?)
A válasz egyik esetben sem lenne megnyugtató, hiszen az egyszerü kapacitás felajánlásánál nyilvánvalóan többről van szó, ugyanakkor ezt a fajta fejlesztési tevékenységet nem lehet összevetni pl. egy gépkocsi fékrendszerének komplett megtervezésével.

A Beszállító F jelenleg kábelkötegeket szállít az Audinak, amelyhez gyártótechnológiát fejlesztett, hamarosan pedig motoralkatrészeket fog szállítani Győrbe.

A Beszállító A, szinte semmilyen saját fejlesztést nem végez, azonban rendelkezik azokkal a technológiákkal, amely nélkül a vevője nem képes (vagy csak sokkal magasabb költségekkel) tesztelni fejlesztési elképzeléseit. A Bosch (adott esetben ő volt a Beszállító A partnere) támaszkodik a Beszállító A gépparkjára, szakembereinek tudására, a Beszállító A mégsem kezdeményezett semmiféle fejlesztést, csupán vevője igényeit elégítette ki, amikor eleget tett a felkérésnek.

A Beszállító G kompetenciája a műszaki gumitermékek gyártása. Saját termékfejlesztést nem végez, a vevői által megadott termékrajzokhoz készíti el a szerszámokat, amelyekkel gyárt. Habár a termék tervezése nem a kompetenciája, jellemzően segíti beszállítóját a tömítés anyagára vonatkozó javaslatokkal, hiszen ezen a területen ő a jártasabb. Esetenként az ő javaslatára a termék anyagát jelentősen megváltoztatják. 
A fenti példák alapján levonhatunk néhány következtetést, ami a beszállítók alapvető képesség szerinti tipizálását illeti:

- az adott mintában található olyan vállalat, amelyik megfelel a kapacitáskompetencia kritériumainak,

- a mintában találunk olyan vállalatot, amely bár nem úgy viselkedik, mint egy klasszikus rendszerintegrátor, mégis rendelkezik a rendszerkompetencia bizonyos fokával, amennyiben több vállalat beszállítói erőfeszítéseit képes koordinálni,

- a mintában több olyan vállalatot találtunk, amely saját (komplett, önmagában is egy egységnek tekinthető) terméket kínál a vevőinek (innovációs kompetencia) és ennek előállítása során bizonyos fokú rendszerkompetenciáról is tanúbizonyságot tesz (saját beszállítóinak körének menedzselése során),

- végül több olyan vállalattal találkoztunk, amelyik nem saját fejlesztésű termékét kínálja, csupán továbbfejlesztette azt, illetve a termék résztulajdonságaival (anyag) kapcsolatosan aktívan segíti a megrendelő fejlesztőit.

Álljon itt még két következtetés a csoportok elkülöníthetőségéről:

1. Az egyes vállalatok nem sorolhatók be tisztán valamely csoportba, kompetenciáik megfelelnek több csoportosítási szempontnak is: pl. miközben (termék) innovációt végeznek, a termék gyártásához szükségszerúen a beszállítói hálózatot is menedzselik.

2. Azok a vállalatok, amelyeknek nem alapvető képessége a fejlesztés, azonban többet nyújtanak a kapacitásaiknál, nem sorolhatóak be megnyugtatóan a hármas csoport valamelyikébe.

E következtetések alapján most már valóban logikusnak látszik elkülönítve kezelni azt a beszállítói csoportot, amely a vevőtől kapott termékspecifikáció alapján kezdi meg egy-egy alkatrész gyártását, azonban az idő múlásával (eleget téve a vevő elvárásainak), ahogyan a tapasztalata nő a termék gyártásában, a vevő jóváhagyásával a terméken módosításokat hajt végre, a gyártási költségek csökkentése vagy a termék egyéb tulajdonságainak javítása érdekében.

A fentiek alapján tehát a Gelei (2004) által leírt négyes osztályozást fogom a további vizsgálathoz modellként használni. Az adott vállalatok esetén az alábbi csoportosítást javaslom (4. táblázat).

\section{A beszállítói értékösszetevők vizsgálata a kutatási eredmények tükrében}

Ebben a részben célom az értékdimenziók és az egyes beszállítói csoportok korábban bemutatott ösz-
4. táblázat

A normatív kutatásban részt vevő vállalatok besorolása alapvető képességeik szerint

\begin{tabular}{|c|c|c|c|}
\hline $\begin{array}{c}\text { Típus 1 } \\
\text { Kapacitás } \\
\text { képesség }\end{array}$ & $\begin{array}{c}\text { Típus 2 } \\
\text { Adaptációs } \\
\text { képesség }\end{array}$ & $\begin{array}{c}\text { Típus 3 } \\
\text { Rendszer } \\
\text { képesség }\end{array}$ & $\begin{array}{c}\text { Típus 4 } \\
\text { Innovációs } \\
\text { képesség }\end{array}$ \\
\hline & & & \\
\hline & & & \\
\hline & & & \\
\hline & & & \\
\hline & & & \\
\hline & & & \\
\hline & & & \\
\hline & & & \\
\hline
\end{tabular}

Jelmagyarázat:

Elsődlegesen jellemző képesség

Másodlagosan jellemző képesség

szekapcsolásának vizsgálata. A kérdés, hogy mennyiben képes pontosan leírni a valóságot az elméleti modell, milyen mértékben rendelhetők hozzá az 1. táblázatban leírt értékdimenziók a valós vállalatok által a vevőik számára nyújtott értékekhez.

Ennek vizsgálatára az 5. táblázatban összefoglaltam, hogy a normatív kutatásban megvizsgált vállalatok esetében a konkrét értékdimenziók közül melyek voltak beazonosíthatóak. Ebben az esetben is csak az interjúalanyok általi közlésekre hagyatkozhattam, amelyek csak a vizsgált ellátási láncokra vonatkoztak. Ennek megfelelően ezek az értékdimenziók az adott vállalatok más vevői esetén eltérőek lehetnek! A táblázatban feltüntettem továbbá a vállalatok előző fejezetben bemutatott alapvető képességek szerinti (4-es) csoportosításának eredményét, ezzel teremtve meg az empirikus kapcsolatot az alapvető képességek és az értékdimenziók között.

A táblázatból látható, hogy az ár mint értékfunkció hangsúlyozottan csak három vállalat esetében jelenik meg (kettőnél itt is csak áttételesen), ahol is elsősorban a nyugati bérszínvonalhoz képest alacsonyabb magyar bérek segítik elő a kedvező árak kialakítását. A többi vállalat esetében az ár kevésbé rendeléselnyerő kritérium, inkább a tárgyalások megkezdéséhez szükséges alap, ún. képesítő kritérium. Autóipari jellegzetesség a végtermékgyártók (OEM-ek) erőfölénye a beszállítóikkal szemben, akik ezért kénytelenek a részletes költségkalkulációikat a vevők rendelkezésére bocsá- 
$\frac{-\sqrt{8}}{\sqrt{2}}$

\begin{tabular}{|c|c|c|c|c|c|c|c|c|c|c|c|}
\hline 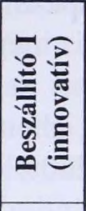 & & 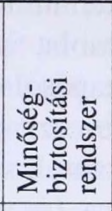 & & 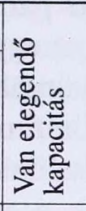 & 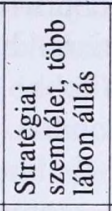 & & 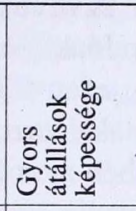 & 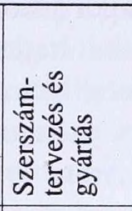 & 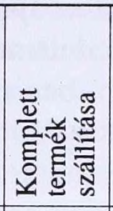 & & \\
\hline 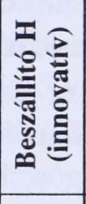 & & 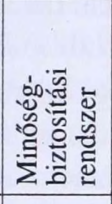 & & 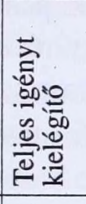 & 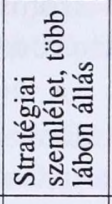 & 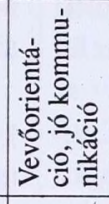 & & 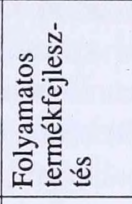 & 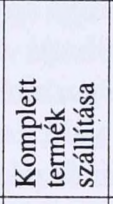 & & \\
\hline 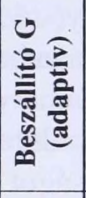 & 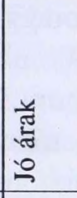 & 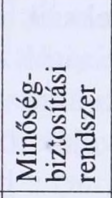 & 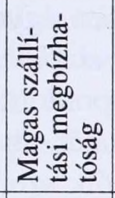 & 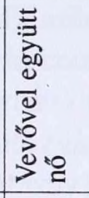 & & 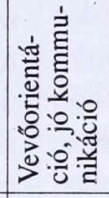 & & 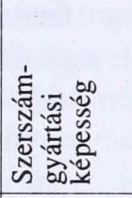 & & & \\
\hline 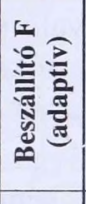 & & 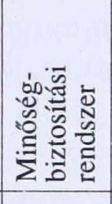 & 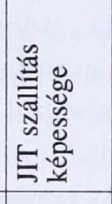 & 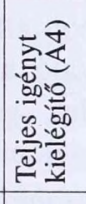 & 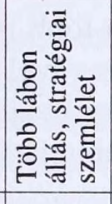 & & & 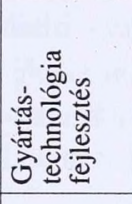 & & & \\
\hline 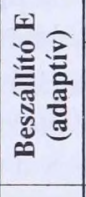 & & 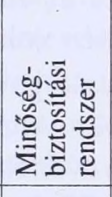 & 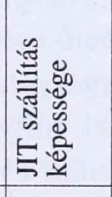 & 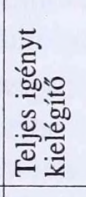 & 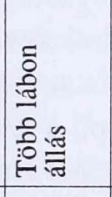 & & & 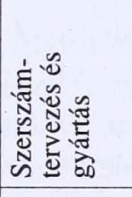 & & & \\
\hline 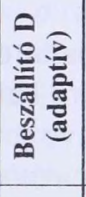 & & 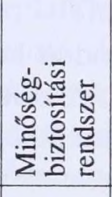 & & 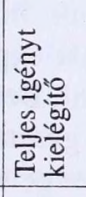 & 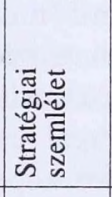 & 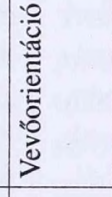 & & 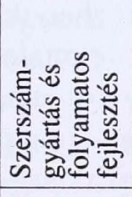 & & & \\
\hline 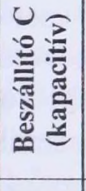 & 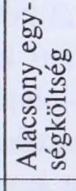 & 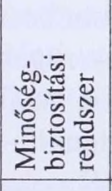 & 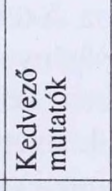 & $\begin{array}{l}0 \\
0 \\
0 \\
0 \\
0 \\
0 \\
0\end{array}$ & 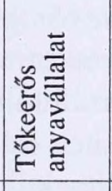 & 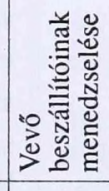 & & & & & \\
\hline 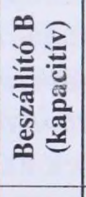 & & 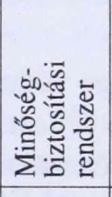 & 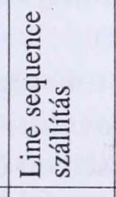 & 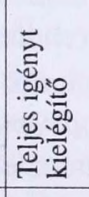 & & & 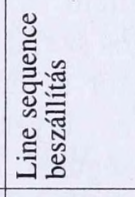 & & & & \\
\hline 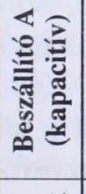 & 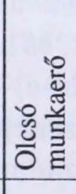 & 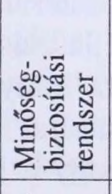 & & 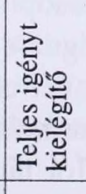 & 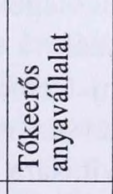 & & 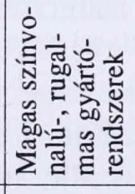 & & & & \\
\hline 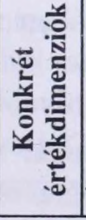 & $1<$ & 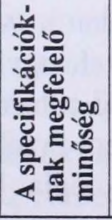 & 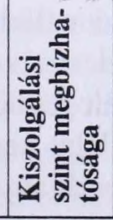 & 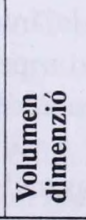 & 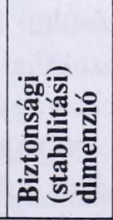 & 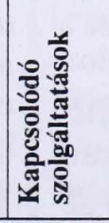 & 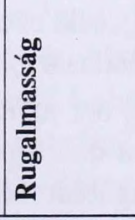 & 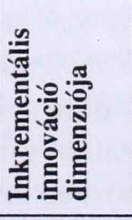 & 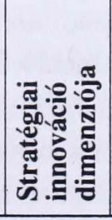 & 脑 & 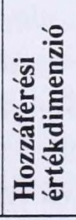 \\
\hline
\end{tabular}


tani egyfajta indoklásként az ajánlati árhoz. A vevők az iparágban elfogadott jövedelemrátát hajlandóak csak a beszállítóik számára az árban megfizetni, ezen fölüli profitot a beszállító csak a költségadatainak „,kozmetikázásával" képes elfogadtatni. Amennyiben azonban a vevő úgy ítéli meg, hogy egy adott költség túlzott mértékű, azt visszautasíthatja és számolhat az általa megfelelőnek ítélt költségszinttel. Ebben az esetben a költségek elvárt szintre való csökkentése a beszállító feladata (problémája). Mindezek alapján tehát egy adott technológiai színvonal, valamint termelésmenedzsment-technikák mellett (amelyek a globális standardként foghatók fel) jelentósen nem térhetnek el a beszállítók árai abban az esetben, amennyiben a felhasznált erőforrásokhoz azonos áron jutnak hozzá (a magyarországi vállalatok esetében ezt feltételezhetjük).

A specifikációnak megfelelö minöség gyakorlatilag alapfeltétele az autóipari beszállításnak, ennek megfelelően minden vállalat rendelkezik tanúsított minőségbiztosítási rendszerrel.

A kiszolgálási szint megbízhatósága, azaz mennyire képes betartani a szállító az ígéreteit, a legtöbb vizsgált vállalat esetén direkt vagy indirekt módon megjelenik az interjúkban ${ }^{5}$. A működő JIT beszállítást, mint a pontos beszállítást értelmezhetjük, így azokban az esetekben, amikor ez fennáll, feltételezem a kiszolgálási szint megbízhatóságát is. Azokban az esetekben, amikor nincs utalás pl. a szállítások pontosságára, csak feltételezésekkel tudunk élni. Valószínűsíthető például, hogy a minőségbiztosítási rendszer megléte hozzájárul a késések elkerüléséhez, azonban semmi esetre sem tekinthető egyértelmű biztosítéknak.

A volumen dimenzió szerint a vizsgált vállalatok mindegyike képes a vevő igényeit kielégíteni. A legtöbb esetben a szállító a termék kizárólagos szállítója. A volumen további növekedésének sokszor az autógyártók maguk szabnak határt, csökkenteni igyekezvén ily módon a beszállítótól való függőségüket. Ennek megfelelően a megfelelő mennyiség szállításának kérdése nem merül fel közvetlenül az interjúkban, habár ez nem jelenti a teljes problémamentességet egy jelentősebb igénynövekedés esetén. (Beszállító I és a Beszállító $\mathrm{G}$ esetében egyértelműen kiderült, hogy amennyiben további kapacitások szükségesek ezek a cégek készek újabb beruházások megvalósítására).

A biztonsági vagy stabilitási dimenzió azt az értéket ragadja meg, amelyet a beszállító mint üzleti partner hosszú távú fennmaradása hordoz magában. Hogy mindez hogyan biztosítható, és fóleg jelen pillanatban hogyan mérhető, arról az egyes vállalatoknak más és más a véleményük. Vannak olyan megrendelők (pl. Bosch), akik a partnerük fennmaradásának zálogát a több üzleti partnerrel fenntartott kapcsolatban látják, hiszen ha az egyik kapcsolat tönkre is megy, attól még a többi gyümölcsöző kapcsolat képes az éppen megromlott által okozott veszteségek ellensúlyozására. Más megrendelők az irántuk való elkötelezettséget és a szoros kapcsolattartást (azaz beszállítóik kapacitásának nagy részét lefoglalva) látják a jövő zálogának.

A különböző meggyőződésekhez természetesen különböző stratégiák, és különböző mérőszámok is tartoznak. Sok esetben nem is világos, hogy a vevő milyen mértékben igyekszik meggyőződni partnerének hosszú távú stabilitásáról. A táblázatban ezért minden olyan szempontot feltüntettem, amely meghatározó lehet a vállalat jövőjét illetően. Jelen vállalatok esetében (vezetőik szerint) a biztonságot legfőképpen a több lábon állás (több termékkel való jelenlét, több vevővel való kapcsolat), a jelentős tőkeerő és/vagy anyavállalat, valamint ezek hiányában a stratégiai előrelátás jelentheti.

A kapcsolódó szolgáltatások legfőképpen a kimondott vevőorientáció esetén voltak értelmezhetőek.

A vevői igényekre való gyors reagálási képességét (pl. a szerződések milyen volumenváltoztatási lehetôséget engednek meg a vevőnek és/vagy a gyakorlatban mit tudnak biztosítani) - vagyis a rugalmasság dimenzióját explicit módon két vállalat esetén tudtuk azonosítani, Beszállító A és Beszállító I esetében, akik rugalmas gyártórendszereikkel, illetve a gyors átállások képességével igyekeznek alkalmazkodni a változó vevői igényekhez. A többi beszállító esetében csak következtetünk az igények rugalmas követésére (pl. Beszállító B esetében, aki a vevő telephelye mellett létesített raktárából közvetlenül a vevő szerelősorára szállítja különböző fajtájú termékeit, a vevő által meghatározott sorrendben.)

A vállalatok többsége végez kis lépésekben megvalósított (inkrementális) fejlesztéseket. Az értékdimenziók ebben az esetben összecsengenek az alapvető képességek csoportosító kritériumával, azaz, hogy a beszállító végez-e saját fejlesztést, és ha igen, a fejlesztés új termék létrehozására irányul-e, vagy a vevő által tervezett termék jobbítására, esetleg a technológia javítására. Jól látható, hogy a jellemzően csak kapacitásukat felajánló vállalatok is általában rendelkeznek szakmai kompetenciával, ugyanakkor ez a kompetencia vagy nem elegendő a termék (tovább)fejlesztéséhez, vagy a vállalat nem érzékeli a fejlesztési kapacitások kihasználását stratégiai lehetőségnek.

A felderitö dimenzió jelenléte explicit módon egyik vállalat esetében sem derül ki, azonban feltételezhető, hogy az e-kommunikáció lehetôséget teremt többletinformációk (esetleg nem ellenőrzött) megszerzéséhez. 
A hozzáférési dimenzió a jelen írásban bemutatott második körös beszállító vállalatoknál nem volt jellemző, mint az értékteremtés egy formája. Meg kell azonban jegyezni, hogy az értékteremtés fordított irányban tapasztalható volt, azaz a beszállító vállalat volt képes a korábbi vevőjén átlépve annak vevője beszállítójává válnia. Az első körös beszállítók esetében már felfedezhető volt az értékteremtés e formája .

A vállalatoknál szerzett tapasztalatok ismertetése után újra lehetőség nyílik a gyakorlatnak az elmélettel való ütköztetésére. Ebben az esetben az 5. táblázat tartalmát kell összevetnünk a korábban bemutatott (a beszállítók alapvető képességeinek és az általuk a vevőiknek nyújtott értéket összekapcsoló) 1. táblázat tartalmával.

Az 5. táblázat felhívja a figyelmet arra, hogy az egyes csoportok esetében jellemző gazdaságossági értékösszetevők átfednek. Így az ár, mint a vevőnek teremtett érték egyik összetevője minden beszállító típus esetében jellemző. Ugyanez érvényes a minőségre vagy az érték mennyiségi összetevőjére. Feltételezhetően a kiszolgálási szint megbízhatósága is ugyanígy jellemző lehet minden vállalatra, erre azonban nincs explicit bizonyíték. Ebből a szempontból az egyes csoportok értékösszetevők szerinti megkülönböztetésre nincs szükség. Ezek szerint elmondható, hogy az autóiparban a vevői értékteremtés gazdaságossági összetevői a beszállitók ${ }^{6}$ számára világosak, érthetöek és azokat a beszállitók (kötelezően) biztositani is képesek. Ebböl továbbá az is következik, hogy a vevői érték növeléséhez (amely hozzájárul a vállalati versenyképesség növekedéséhez is) további értékösszetevőket kell növelni.

Ennek a felismerésnek lehet a következménye az a jelenség, amely az inkrementális innovációs képességek megjelenéséhez vezetett, illetve ennek köszönhető az integrátori szerepkörök alacsonyabb beszállítói sziritekre történő szorítása. Mindkét jelenség annak a bizonyítéka, hogy a hagyományos értékösszetevőkben (ár, minőség) rejlő lehetőségek kimerülőben vannak, az értéknövelésnek más módját kell kialakítani. Ennek megfelelően indokolt a hatékonysági és az indirekt értékösszetevők kimerítőbb tanulmányozása, hiszen ezekben csírázhat a jövő sikere.

Ezen a ponton célszerű visszatérnünk Gelei (2004) táblázatára, ahol az általa kialakított négy beszállítói csoport általános jellemzését adja (1. táblázat).

Gyakorlati tapasztalataink alapján érdemes kissé átalakítani a táblázatot. Az eredeti táblázat oszlopainak sorrendje egyben a beszállítók alkuerejének alakulását is mutatja. Ennek megfelelően a kapacitását felajánló beszállító rendelkezik a legcsekélyebb alkuerővel, majd a rendszer kompetenciájú beszállító következik, azután az adaptálni képes beszállító, és végül az innovátor. Véleményem szerint az adaptációs képesség egyre inkább a kapacitás felajánlásának kiegészítőjévé válik, így az ehhez kapcsolódó alkuerő idővel jelentősen csökkeni fog. Ezzel szemben a rendszerek gyártását menedzselni képes beszállító felértékelődhet, hiszen ő válik a vevő (egyre kisebb létszámú) közvetlen partnerévé. Így várhatóan alkuereje a jövőben nőni fog. Amenynyiben feltételezzük azt is, hogy a rendszerek gyártása kiegészül azok fejlesztésével is, akkor a rendszerkompetencia az alkuerő legmagasabb szintjét érheti el, maga mögé utasítva a tisztán fejlesztési kompetenciával rendelkező vállalatokat. Ezt az elméletet támasztják alá azok a vélemények is, melyek a komplex, nehezen másolható, nehezen elcsábítható tudást tartják a siker forrásának a jövőben (Grant, 1991; Prahalad - Hamel, 1993; Loasby, 1994). A technológiákban meglévő előny a technológia másolásával átvihető, a szakemberek, kutatók elcsábíthatóak. Az átvihetőségnek azok a rendszerben meglévő tudások állnak leginkább ellent, amelyek komplex kapcsolatok működésével jönnek létre, sok résztvevő járul hozzá a sikeréhez.

Ennek megfelelően a 1. táblázat javasolt módosítását a 6. táblázat tartalmazza.

Meg kell jegyezni továbbá, hogy a táblázat ilyen módon való felépítése jelenti az egyes típusok egymásra épülését. A jobb oldali oszlopokban szereplő beszállítók jellemzően képesek szolgáltatni vevőik számára a tőlük balra található oszlopban leírt beszállítók nyújtotta értékeket is.

\section{Összefoglalás}

Napjainkban egyre több szó esik a vállalatok versenyképességéről, annak fokozásáról. Minthogy a versenyképességnek egyik alapvető eleme az az érték, amelyet egy vállalat a vevői számára szolgáltatni tud, ezért itt az érték létrehozásához szükséges tényezôt, a képességeket vizsgáltuk.

Jelen írásban azt mutattam be, hogy a Gelei - Nagy (2004) szerzőpáros által a hazai autóiparban azonosított, a beszállítók által a vevőiknek nyújtott értékek és a Gelei (2004) által adott, a beszállítók alapvető képességeit alapul vevő négyes besorolás hogyan kapcsolódik. Mely értékek mely képességekhez kapcsolódnak? Lehet-e rangsorolni a beszállítókat képességeik alapján? Ennek a kapcsolatnak a bemutatására a hazai autóipari beszállítók példáit használtam fel.

Az elemzés megmutatja hogy az alapvető beszállítói képességek és ezen képességek felhasználásával a vevő számára teremtett értékek összefüggenek. Az adott példák alapján a beszállítók rangsorba állíthatók 
Az egyes beszállító típusok és jellemzőik

\begin{tabular}{|c|c|c|c|c|}
\hline Beszállítói típus & Kapacitás kompetencia & Adaptáció kompetencia & Innováció kompetencia & Rendszer kompetencia \\
\hline Termék-csomag & Kapacitás & $\begin{array}{l}\text { Termékismeret és } \\
\text { technológia }\end{array}$ & Magas innovációs képesség & Kapcsolati háló \\
\hline $\begin{array}{l}\text { Fóbb } \\
\text { értékdimenziók }\end{array}$ & Ár & Rugalmasság & Innováció & $\begin{array}{l}\text { Beszállítói kapcsolatok szé- } \\
\text { lessége és kapcsolatkezelés }\end{array}$ \\
\hline $\begin{array}{l}\text { Alapvetö képes- } \\
\text { ség }\end{array}$ & $\begin{array}{l}\text { Gazdaságos termelési } \\
\text { képesség }\end{array}$ & $\begin{array}{l}\text { Inkrementális innová- } \\
\text { ciós képesség }\end{array}$ & Stratégiai innovációs képesség & Hálózati képesség \\
\hline $\begin{array}{l}\text { Legfontosabb } \\
\text { erōforrások }\end{array}$ & $\begin{array}{l}\text { Olcsó munkaerő, alkal- } \\
\text { mazott technológia }\end{array}$ & $\begin{array}{l}\text { Képzett, tapasztalt mun- } \\
\text { kaerő }\end{array}$ & $\begin{array}{l}\text { Magasan képzett } \mathrm{K}+\mathrm{F} \\
\text { alkalmazottak, Legfejlettebb } \\
\text { kutatási technológia beszerzése }\end{array}$ & $\begin{array}{l}\text { Integrált, a partnerekkel } \\
\text { összeköttetésben lévố } \\
\text { információs rendszer }\end{array}$ \\
\hline $\begin{array}{l}\text { Legfontosabb } \\
\text { részképességek }\end{array}$ & $\begin{array}{l}\text { Gyártási folyamat } \\
\text { szervezettsége }\end{array}$ & $\begin{array}{l}\text { A vevő igényeinek } \\
\text { megértési képessége, } \\
\text { Hatékony termelési } \\
\text { képesség }\end{array}$ & $\begin{array}{l}\text { Technológiai és piaci trendek jó } \\
\text { felismerési képessége, Stratégiai } \\
\text { partnerkapcsolatok kialakításának } \\
\text { és hatékonymenedzsmentjének } \\
\text { képessége }\end{array}$ & $\begin{array}{l}\text { Hatékony beszállító-érté- } \\
\text { kelés és kiválasztás, Jó ko- } \\
\text { ordinációs, és probléma- } \\
\text { megoldó képesség }\end{array}$ \\
\hline Kapcsolat típus & $\begin{array}{l}\text { Rövid távú - piaci } \\
\text { cserekapcsolat }\end{array}$ & Középtávú - kooperáció & $\begin{array}{l}\text { Hosszú távú - stratégiai partner- } \\
\text { kapcsolatok }\end{array}$ & $\begin{array}{l}\text { Hosszú távú - stratégiai } \\
\text { partnerkapcsolatok }\end{array}$ \\
\hline Alkuerö & \multicolumn{4}{|l|}{ Kicsi } \\
\hline
\end{tabular}

a szerint, hogy milyen alapvető képességekkel rendelkeznek. A rangsorban a kapacitás képesség áll leghátul, az ezzel a képességgel rendelkező vállalat képes a vevője számára a legkevesebb fajta értéket teremteni. A következő szint az adaptációs képesség, majd a rendszer és az innovációs képesség. Véleményem szerint ezek a képességek egymásra épülnek a magasabb szintek képesek a sorban előttük álló szintek teremtette értéket is szolgáltatni.

A cikk gyakorlati példákat sorol fel az egyes alapvetô kompetenciákhoz kapcsolódó értékek szemléltetésére. Ez a felsorolás segíthet más vállalatok számára is kompetenciáik, és az általuk nyújtott értékek számbavételéhez, valamint a vállalat fejlődési útjának kijelöléséhez.

\section{Felhasznált irodalom}

Chikán, A. (2001): A hazai versenyképességi kutatások koncepcionális kerete és gyakorlati relevanciája; ,A versenyképesség koncepcionális háttere és alakulása a XXI. Század küszöbén" címủ tudományos konferencia elóadáskötete; BKAE Vállalatgazdaságtan Tanszék

Chikán, A. - Demeter, K. (szerk.) (2003): Értékteremtô folyamatok menedzsmentje, Aula Kiadó Budapest, o. 4-14, és 24-36.

Demeter, K. - Gelei, A. - Jenei, I. (2004): A vállalati stratégia hatása az ellátási lánc menedzsmenteszközeire; Vezetéstudomány, XXXV. Évfolyam, 4. szám, 33-47. o.

Gelei A. (2004): Beszállító-típusok és azok alapvető képességei a hazai autóipari ellátási láncban, PhD Kutatási tervezet, BKÁE Vállalatgazdaságtan tanszék

Gelei, A. - Nagy J. (2004): Partnerkapcsolatok értéke a hazai autóipari ellátási láncban - fókuszban a beszállító vállalatok; BKÁE Vállalatgazdaságtan tanszék Mühelytanulmány

Grant, R. M. (1991): The Resource-Based Theory of Competitive Advantage: Implication for Strategy Formulation, California Management Review
Haffmans, L. - van Weele, A, (2003): How suppliers can become innovative; 12th International IPSERA Conference in Budapest, Proceedings

Loasby, B. J. (1994): Organisational capabilities and interfirm relations; Metroeconomics, 45: pp. 248-265.

Mandják T. - Durrieu, F (2000): Understanding the non-economic value of business relationships; 16th Annual IMPConference, Proceedings, CD Rom, Bath, pp. 1-16.

Möller, K. - Törrönen, P. (2003): Business suppliers' value creation potential. A capability-based analysis in. Industrial Marketing Management, Vol. 32, pp. 109-118.

Nelson, R. - Winter, S. (1982): An Evolutionary Theory ofeconomic Change; Belknap, Cambridge, $\mathrm{ME}$

Walter, A. - Ritter, T. - Gemünden, H. G. (2001): Value-cration in buyer - seller relationships; theoretical considerations and empirial results from a supplierls perspective; Industrial Marketing Management, 30 , pp. $365-377$.

Walters, D. (2002): Operations strategy; Palgrave - MacMillan

\section{Lábjegyzetek}

1 A legfontosabb erôforrások, illetve részképességek esetében csak példák szerepelnek, azok teljes körû̉ összegyűjtése, strukturálása késổbbi kutatás feladata.

2 Zipzárak nagy tömegben való előállítására szakosodott vállalat.

3 Demeter, K. - Gelei, A. - Jenei, I. (2004): A vállalati stratégia hatása az ellátási lánc menedzsment eszközeire; Vezetéstudomány, XXXV. Évfolyam, 4. szám, 33-47. o.

4 Pl. teljes műszerfal vagy teljes futómû,

5 A normatív kutatás (Demeter - Gelei - Jenei, 2004) során 13 vállalat vezetőivel készítettünk interjút. Jelen kutatáshoz felhasználom ezen interjúk anyagait.

6 Szeretném újra kiemelni, hogy itt évek óta teljesítő beszállítókról van szó, nem pedig pályázó beszállítókról!

7 A legfontosabb erőforrások, illetve részképességek esetében csak példák szerepelnek, azok teljes körû́ összegyûjjtése, strukturálása késôbbi kutatás feladata.

$8 \mathrm{Az}$ azonosított vevői értékdimenziók: ár, minőség, mennyiség, stabilitás, szolgáltatások, rugalmasság, innováció, felderítés, hozzáférés. 